Journal of Social Sciences 6 (2): 287-292, 2010

ISSN 1549-3652

(C) 2010 Science Publications

\title{
Pilot Investigation on the Mismatches of Classroom Furniture and Student Body Dimensions in Malaysian Secondary Schools
}

\author{
Raja Ariffin Raja Ghazilla, Zahari Taha, Suraya Kamaruddin and Iskandar Hasanuddin \\ Department of Engineering Design and Manufacture, Faculty of Engineering, \\ Centre for Product Design and Manufacturing, University of Malaya, Kuala Lumpur 50603, Malaysia
}

\begin{abstract}
Problem statement: This study is an investigation of the mismatch between chair and desk dimensions and student body dimensions. Approach: The objective of this study was to determine whether design improvement and further study is required in order to improve the conditions in Malaysian primary schools. Results: The supplied standard government issued classroom furniture was measured and anthropometrics measurements data were collected from 300 students from three pilot study schools in Kuantan, Pahang covering the age group between 13-17 years. The pilot data indicate a substantial degree of mismatch between the student body dimensions and the classroom furniture. The chair is either too high or too deep for the students. The data also shows that the desk is too high for most of the students. The variability between gender and age was found to have profound impact on the mismatch levels. Conclusion/Recommendations: The result is of great concern which could pose students with the risk of having back problems in the future.
\end{abstract}

Key words: Classroom furniture, anthropometric mismatch, student body dimension

\section{INTRODUCTION}

Malaysian school children spend a large part of their day sitting in a classroom environment comprising the normal school hours as well as the almost daily routine of tuition classes. This prolonged sitting posture most often without support from a backrest makes them susceptible to risk of suffering negative effects from badly design and ill fitting furniture (Evans et al., 1992). Furniture wrongly designed and ill fitted to the characteristics of a child can result in defective posture and the establishment of pathological states which could affect their performance in focusing in class and faster fatigue occurrence (Lane and Richardson, 1993). Various studies have shown that the ill fitted design of classroom furniture have contributed to the high incidence of musculoskeletal disorders among school children (Olsen et al., 1992). This trend might also be present in the Malaysia but currently there is no study which indicates this. The issue of back problems is prevalent in the industry whereby the cost of solving this problem is ever increasing. Tackling this problem at the initial stage in schools would be of great importance. The design of chairs and desks for the workplace has been studied with great interest and yet little interest has been shown in a school which under the Malaysian OSHA Act constitutes as part of the workplace whereby the students must be given the same attention (Malaysian Occupational Safety and Health Act, 1994). Thus the design of chair and desk must be emphasized as required by the act. This study was conducted not to determine the existence of back problems among student but to asses the fitness of the chair and desk which could be an indicator of possible back problems among students. This pilot investigation examines the possible mismatches between the individual body dimensions of Malaysian primary students and the standard classroom furniture made available to them by the school authorities. This study would help in establishing and motivating the necessary further studies in classroom ergonomics with special attention to chair and desk.

\section{MATERIALS AND METHODS}

A total of 300 students consisting of equal numbers of male and female students were studied. Their ages range from 13-17 years old. The student were randomly selected covering each level of secondary school education. Measurement is done with a teacher present during the measurement. Figure 1 shows the desk and chair currently used in the schools.

Corresponding Author: Raja Ariffin Raja Ghazilla, Department of Engineering Design and Manufacture, Faculty of Engineering, Centre for Product design and Manufacture, University of Malaya, Kuala Lumpur 50603, Malaysia Tel: 60379675369 Fax: 60379675330 


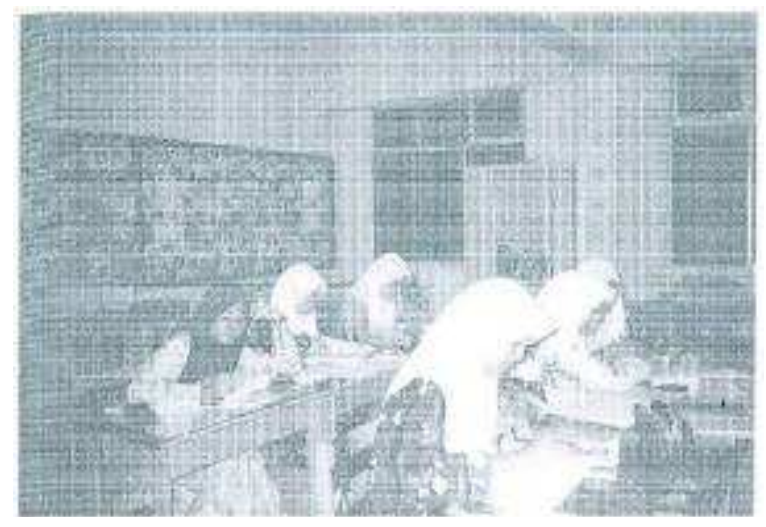

Fig. 1: Desk and chair currently used by both schools

Table 1: Students body dimensions

\begin{tabular}{|c|c|}
\hline Parameter & Measurements method \\
\hline Stature & $\begin{array}{l}\text { Measured as the vertical distance from the floor to } \\
\text { the top of the head, while the students stood erect, } \\
\text { looking straight ahead. }\end{array}$ \\
\hline Elbow height & $\begin{array}{l}\text { Measured with the elbow flexed at } 90 \text {, as the } \\
\text { vertical distance from the bottom of the tip of the } \\
\text { elbow to the student's seated surface }\end{array}$ \\
\hline Shoulder height & $\begin{array}{l}\text { Measured as the vertical distance from the top of } \\
\text { the shoulder at the acromiom process to the } \\
\text { student's sitting surface. }\end{array}$ \\
\hline Upper arm length & $\begin{array}{l}\text { Difference between the elbow height and shoulder } \\
\text { height. }\end{array}$ \\
\hline Knee height & $\begin{array}{l}\text { Measured with knee flexed at } 90 \text {, as the vertical } \\
\text { distance from the foot resting surface to be top of } \\
\text { the knee cap, just above the patella. }\end{array}$ \\
\hline Popliteal height & $\begin{array}{l}\text { Measured with a } 90 \text {, knee flexion, from the foot } \\
\text { resting surface to the popliteal space, which is the } \\
\text { posterior surface of the knee. }\end{array}$ \\
\hline $\begin{array}{l}\text { Buttock-popliteal } \\
\text { length } \\
\text { (thigh length) }\end{array}$ & $\begin{array}{l}\text { Measured with the knee flexed at } 90 \text {, as the distance } \\
\text { from the posterior surface of the buttock to the } \\
\text { posterior surface of the knee or popliteal surface. }\end{array}$ \\
\hline
\end{tabular}

Body measurements: In this study, stature dimensions for each child are taken while they are standing. All other dimensions measured while they are sitting erect on chair with knees bent at 90 . For both measurements they are barefooted flat on a flat horizontal floor surface. Students are dressed in light sports attire. Table 1 shows the body dimensions measured in this study.

Furniture measurements: For both schools the design and the size of the desk and chair are similar as it is standard government issued furniture. The dimensions of the classroom furniture are shown in Table 2 .

Statistical analysis was employed in order to determine the mean, standard deviation and standard error of the anthropometrics data that have been collected.
Table 2: Chair and desk dimensions

\begin{tabular}{|c|c|}
\hline Parameter & Measurement method \\
\hline Seat height & $\begin{array}{l}\text { Measured as a distance from the floor to the highest } \\
\text { point on the front of the seat. }\end{array}$ \\
\hline Seat depth & $\begin{array}{l}\text { Measured from the back of the sitting surface of the } \\
\text { seat to its front. }\end{array}$ \\
\hline Seat slope & $\begin{array}{l}\text { Direction and angle of the slope of the seat's sitting } \\
\text { surface. }\end{array}$ \\
\hline Desk height & $\begin{array}{l}\text { Measured from the floor to the top of the front edge } \\
\text { of the desk. }\end{array}$ \\
\hline $\begin{array}{l}\text { Desk } \\
\text { clearance }\end{array}$ & $\begin{array}{l}\text { Measured from the floor to the bottom of the front } \\
\text { edge of the shelf under the writing surface. }\end{array}$ \\
\hline Desk slope & Angle at which the writing surface of the desk slope. \\
\hline
\end{tabular}

Anthropometrics mismatches: The number and percentage of the students where the body match or mismatch with the furniture is calculated based on the rules adapted from (Parcells et al., 1999; Chaffin and Anderson, 1991). A mismatch is defined as incompatibility between dimensions of the student's body dimension. The mismatch rules are followed in order to determine mismatch between certain body dimensions and its corresponding design parameter as listed below.

Popliteal height and seat height mismatch: A mismatch is defined when the seat height was either $>95 \%$ or $<88 \%$ of the popliteal height.

Buttock-popliteal length and seat depth mismatch: A mismatch is defined when the seat depth was either $>95 \%$ or $80 \%$ of the popliteal height.

Knee rest height and desk height mismatch: A mismatch is defined as occurring when a desk was $<2 \mathrm{~cm}$ higher than the knee height.

Elbow rest height and desk height mismatch: According to Parcells et al. (1999) acceptable desk height is determined by the following equation:

$\mathrm{hE}=\mathrm{hEv}+\mathrm{U}[(1-\cos \theta)+\cos \theta(1-\cos \beta)]$

Where:

$\mathrm{hE}=$ The vertical distance from the top of the desk to the student's sitting surface

$\mathrm{hS}=$ The shoulder height

$\mathrm{hEv}=$ The elbow height

$\mathrm{U}=\mathrm{hS}-\mathrm{hEv}$ is the upper arm length

$(\theta)=$ Shoulder flexion

$(\beta)$ = Shoulder abduction

According to Chaffin and Anderson (1991), the minimum and maximum acceptable angle of the shoulder during writing is $0-25^{\circ}$ for shoulder flexion and $0^{\circ}-20^{\circ}$ for shoulder abduction. For flexion angles the corresponding cosines are $1\left(0^{\circ}\right)$ and $0.9063\left(25^{\circ}\right)$ and for abduction angles the corresponding cosines are $1\left(0^{\circ}\right)$ and $0.9397\left(20^{\circ}\right)$. Applying the cosines to the 


\section{J. Social Sci., 6 (2): 287-292, 2010}

Eq. 1, desk height is determined by the following equations:

Minimum desk height $=$ seat height $+\mathrm{hE}$

Where hE $=\mathrm{hEV}+\mathrm{U}[(1-1)+1(1-1)]=\mathrm{hEv}$

Maximum desk height $=$ seat height $+\mathrm{hE}$

Where:

$$
\begin{aligned}
\mathrm{hE} & =\mathrm{hEv}+\mathrm{U}[(41-\cos \theta)+\cos \theta(1-\cos \beta)] \\
& =\mathrm{hEv}+\mathrm{U}[(41-0.9063)+0.9603(1-0.9397)] \\
& =0.8517 \mathrm{hEv}+0.1483 \mathrm{Hs}, \text { since } \mathrm{U}=\mathrm{hS}-\mathrm{hEv}
\end{aligned}
$$

Based on the above dimensions, it is concluded that a mismatch of elbow-shoulder height and desk height is defined as when the desk was either shorter than the minimum desk height or taller than the maximum desk height.

\section{RESULTS}

School furniture dimensions: The design of the chair and desk is common for both schools which were issued by the state education's supplier. Each grade is provided with the same type of chairs and desk. The design is purely traditional using wood as the material. The measurement for the chair and desk is shown in Table 3. It is interesting to note there was no accommodation for back angle which would be commonly applied to support and reduce stresses at the lumbar back region.

Anthropometrics measurements of students: Table 48 shows the student body dimensions for each level of education. Table 9 is a summary of the overall anthropometrics data. The variability of growth at these ages has an influence towards the standard deviation.

Table 3: Average dimensions of the standard government issued chair and desk

\begin{tabular}{|c|c|c|c|c|c|c|c|c|c|c|c|c|c|c|c|c|}
\hline \multirow{2}{*}{$\begin{array}{l}\text { Anthropometric } \\
\text { Dimensions }\end{array}$} & \multicolumn{8}{|c|}{ Boys $(n=60)$} & \multicolumn{8}{|c|}{ Girls $(\mathrm{n}=30)$} \\
\hline & Mean & SD & Min & Median N & Max & $5 \%$-ile 5 & $50 \%$-ile 9 & $95 \%$-ile $\mathrm{N}$ & Mean S & SD & Min & Median & $\operatorname{Max}$ & $5 \%$-ile & $50 \%$-ile & 95\%-ile \\
\hline Stature & 152.9 & 1.112 & 151.0 & 152.801 & 156.0 & $\begin{array}{ll}151.00 \quad 1 \\
\end{array}$ & $\begin{array}{ll}152.75 & 1\end{array}$ & $\begin{array}{l}154.70 \quad 1 \\
\end{array}$ & 153.0 & 1.604 & 148.0 & 153.0 & 156.0 & 150.20 & 153.0 & 155.6 \\
\hline Elbow height & 20.23 & 0.914 & 19.0 & 20.00 & 22.0 & 18.73 & 20.00 & 21.73 & 19.8 & 0.840 & 19.0 & 19.5 & 22.3 & 18.45 & 19.5 & 21.21 \\
\hline height & 47.95 & 0.644 & 46.9 & 48.00 & 49.0 & 46.90 & 48.00 & 49.01 & 48.3 & 0.923 & 46.9 & 48.1 & 51.0 & 46.75 & 48.1 & 49.78 \\
\hline Upper & 27.72 & 1.161 & 25.7 & 27.65 & 30.0 & 25.82 & 27.65 & 29.62 & $28.4 \quad 1$ & 122.000 & 26.4 & 28.5 & 31.0 & 26.43 & 28.5 & 30.43 \\
\hline Sitti & 48.06 & 0.635 & 46.9 & 48.00 & 49.4 & 47.02 & 48.00 & 49.10 & 48.1 & 0.798 & 46.9 & 48.0 & 50.4 & 46.83 & 48.0 & 49.42 \\
\hline neight & 39.84 & 1.015 & 38.0 & 40.00 & 41.0 & 38.17 & 40.00 & 41.50 & 40.0 & .125 & 38.0 & 40.1 & 42.0 & 38.14 & 40.1 & 41.83 \\
\hline ht & 39.56 & 0.956 & 38.0 & 40.00 & 41.0 & 37.90 & 40.00 & 41.13 & 39.6 & 0 & 38.0 & 40.0 & 43.0 & 37.73 & 40.0 & 41.37 \\
\hline Wei & 40.44 & 1.270 & 38.0 & 40.75 & 42.5 & 38.38 & 40.75 & 42.53 & 40.1 & 1.319 & 38.0 & 40.0 & 43.0 & 37.95 & 40.0 & 42.28 \\
\hline \multicolumn{17}{|c|}{ able 5: Students aged 14 years old $(n=6$} \\
\hline Anthropometric & \multicolumn{8}{|c|}{ Boys $(n=30)$} & \multicolumn{8}{|c|}{ Girls $(\mathrm{n}=30)$} \\
\hline Dimensions & Mean & SD & Min & Median & Max & $5 \%$-ile & $50 \%$-ile & $95 \%$-ile & e Mean & SD & Min & Median & Max & $5 \%$-ile & $50 \%$-ile & 95\%-ile \\
\hline Stature & 154.10 & 1.609 & 152.0 & 163.80 & 158.0 & 15.15 & 153.81 & 156.70 & 154.0 & 1.644 & 149.0 & 154.5 & 157.0 & 151.70 & 154.5 & \\
\hline & & 0.814 & & & 215.0 & & & & & 0.560 & 19.0 & & 21.0 & 18.58 & .5 & \\
\hline ht & 48.26 & 0.921 & 46.9 & 48.10 & 51.0 & 46.75 & 48.1 & 49.77 & 48.7 & 0.860 & 47.0 & 48. & 50.5 & 47.24 & 48.5 & \\
\hline Upp & 28.51 & 1.253 & 25.8 & 28.50 & 32.0 & 26.45 & 28.5 & 30.56 & 29.2 & 0.978 & 26.0 & 29.3 & 31.0 & 27.55 & 29.3 & \\
\hline & & 1.013 & & & 51.0 & ) & 48 & & 48.8 & & 47.0 & & 51.0 & 47.07 & 48.5 & \\
\hline & 9 & 0.991 & 38.0 & 40.50 & 42.5 & 38.75 & 40.5 & 42.02 & 41.3 & 0.744 & 40.0 & 41. & 43.0 & 40.10 & 41.0 & \\
\hline & 39.93 & 1.054 & 38.0 & 40.00 & 41.5 & 38.20 & 40.0 & 41.66 & 40.0 & 1.055 & 38.0 & 40.0 & 41.5 & 38.25 & 40.0 & \\
\hline Weight $(\mathrm{kg})$ & 43.88 & 0.905 & 42.5 & 44.00 & 46.0 & 42.39 & 44.0 & 45.36 & 42.7 & 1.874 & 38.5 & 43.0 & 45.5 & 39.59 & 43.0 & 45.74 \\
\hline \multicolumn{17}{|c|}{ able 6: Students aged 15 years old $(n=$} \\
\hline Anthropometric & \multicolumn{8}{|c|}{ Boys $(\mathrm{n}=30)$} & \multicolumn{8}{|c|}{ Girls $(\mathrm{n}=30)$} \\
\hline Dimensions & Mean & SD & Min & Median & $\operatorname{Max}$ & $5 \%$-ile & $50 \%$-ile & $95 \%$-ile & e Mean & $\mathrm{SD}$ & Min & Median & $\operatorname{Max}$ & $5 \%$-ile & $50 \%$-ile & $95 \%$-ile \\
\hline Statu & 157.420 & 2.470 & 154.0 & 157.25 & 163.0 & 153.370 & $0 \quad 157.25$ & 161.50 & 155.30 & 2.449 & 149.5 & 154.75 & 160.5 & 151.20 & 154.75 & 159.30 \\
\hline Elbo & 19.437 & 0.562 & 18.5 & 19.50 & 20.8 & 18.515 & $\begin{array}{ll}5 & 19.50\end{array}$ & 20.36 & 19.34 & 0.581 & 18.0 & 19.40 & 20.8 & 18.38 & 19.40 & 20.29 \\
\hline Sitting & 50.333 & $3 \quad 1.802$ & 47.0 & 51.15 & 52.5 & 47.379 & 951.16 & 53.29 & 49.17 & 1.028 & 48.0 & 49.00 & 51.0 & 47.49 & 49.00 & 50.85 \\
\hline & & 7.929 & & 31.55 & 33.5 & 27.733 & $3 \quad 31.55$ & 34.06 & 29.63 & 31.339 & 27.7 & & 33.0 & 27.64 & 9.50 & 32.03 \\
\hline & 49.520 & 1.296 & 48.0 & 49 & 52.0 & & $4 \quad 49.00$ & 51.65 & 49.39 & 1.191 & 48.0 & & 52.0 & 47.44 & 49.00 & 51.35 \\
\hline Sitti & 41.870 & 0.751 & 40.5 & 42.00 & 43.0 & 40.639 & $9 \quad 42.00$ & 43.10 & 41.55 & 0.810 & 40.0 & 41.50 & 42.5 & 40.23 & 41.50 & 42.88 \\
\hline & & 0.811 & 40.0 & 41.50 & 43.0 & & $7 \quad 41.50$ & 42.95 & 41.05 & 0.820 & 40.0 & 41.00 & 42.5 & 39.71 & 41.00 & 42.39 \\
\hline Weight ( & 49.520 & 1.296 & 48.0 & 49.00 & 52.0 & 47.394 & $4 \quad 49.00$ & 51.66 & 43.52 & 2.079 & 38.5 & 43.50 & 51.8 & 38.57 & 43.50 & 48.48 \\
\hline
\end{tabular}

\begin{tabular}{ll}
\hline Parameter & Dimension range \\
\hline Seat height & $42-43 \mathrm{~cm}$ \\
Seat depth & $39.5-41 \mathrm{~cm}$ \\
Seat slope & 0 \\
Desk height & $77.9-79 \mathrm{~cm}$ \\
Desk clearance & $63.5-65.5 \mathrm{~cm}$ \\
Surface angle & 0 \\
\hline
\end{tabular}

Table 4: Students aged 13 years old $(n=60)$ 
Table 7: Students aged 16years old $(n=60)$

\begin{tabular}{|c|c|c|c|c|c|c|c|c|c|c|c|c|c|c|c|c|}
\hline \multirow{2}{*}{$\begin{array}{l}\text { Anthropometric } \\
\text { Dimensions }\end{array}$} & \multicolumn{8}{|c|}{ Boys $(n=30)$} & \multicolumn{8}{|c|}{ Girls $(\mathrm{n}=30)$} \\
\hline & Mean & SD & Min & Median & Max & $5 \%$-ile & $50 \%$-ile & $95 \%$-ile & Mean & SD & Min & Median & $\operatorname{Max}$ & $5 \%$-ile & $50 \%$-ile & 95\%-ile \\
\hline Stature & 162.10 & 3.25 & 158 & 162.0 & 170.0 & 157.0 & 161.8 & 167.0 & 156.5 & 35.0 & 149 & 155.0 & 164.0 & 151.00 & 0155.0 & 162.30 \\
\hline Elbow height & 19.19 & 0.46 & 18 & 19.1 & 20.0 & 18.4 & 19.1 & 20.0 & 19.19 & 0.6 & 18 & 19.0 & 20.5 & 18.30 & 19.0 & 20.11 \\
\hline Sitting shoulder height & 53.27 & 1.84 & 49 & & & 50.6 & 53.4 & & 49 & 1.2 & 48 & 49.8 & 51.8 & 47.70 & 49.8 & 51.55 \\
\hline Upper arm length & 34.08 & 1.74 & 30 & 34.1 & 39.0 & 31.2 & 34.05 & 36.9 & 30.43 & 1.2 & 28 & 30.5 & 32.8 & 28.40 & 30.5 & 32.43 \\
\hline Sitting knee height & 51.47 & 1.40 & 50 & 51.4 & 56.0 & 49.2 & 51.35 & 53.8 & 50.04 & 1.5 & 48 & 50.5 & 53.0 & 4.61 & 50.5 & 52.48 \\
\hline Sitting popliteal height & 42.51 & 0.72 & 41 & 42.5 & 44.0 & 41.3 & 42.60 & 43.7 & 41.95 & 0.8 & 41 & 42.0 & 43.0 & 40.70 & 42.0 & 43.19 \\
\hline Buttock popliteal height & 42.06 & 0.73 & 41 & 42.3 & 43.2 & 40.9 & 42.25 & 43.3 & 41.51 & 0.9 & 40 & 41.3 & 42.8 & 10.00 & 41.3 & 42.99 \\
\hline Weight (kg) & 54.48 & 1.88 & 52 & 54.0 & 60.0 & 51.4 & 54.00 & 57.6 & 51.26 & 29.0 & 48 & 50.5 & 58.0 & 46.60 & 50.5 & 55.95 \\
\hline
\end{tabular}

Table 8: Students aged 17years old $(n=60)$

\begin{tabular}{|c|c|c|c|c|c|c|c|c|c|c|c|c|c|c|c|c|}
\hline \multirow{2}{*}{$\begin{array}{l}\text { Anthropometric } \\
\text { Dimensions }\end{array}$} & \multicolumn{8}{|c|}{ Boys $(n=30)$} & \multicolumn{8}{|c|}{ Girls $(n=30)$} \\
\hline & Mean & SD & Min & Median & Max & $5 \%$-ile & $50 \%$-ile & $95 \%$-ile & Mean & SD & Min & Median & Max & $5 \%$-ile & $50 \%$-ile & $95 \%$-ile \\
\hline Stature & 164.90 & 3.97 & 158 & 165.0 & 174.0 & 158.0 & 165.0 & 171.0 & 157.50 & 3.7 & 150 & 157.0 & 164.0 & 151.0 & 157.0 & 163.50 \\
\hline Elbow Height & 18.81 & 0.58 & 18 & 19.0 & 19.5 & 17.9 & 19.0 & 19.8 & 19.29 & 0.5 & 19 & 19.4 & 20.2 & 18.5 & 19.4 & 20.04 \\
\hline Sitting shoulder height & 54.60 & 1.47 & 52 & 54.4 & 4.8 & 52.2 & 54.4 & 57.0 & 51.59 & 0.8 & 50 & 51.8 & 53.0 & 50.2 & 51.8 & 52.96 \\
\hline Upper arm length & 35.79 & 1.57 & 33 & 35.5 & 40.2 & 33.2 & 35.5 & 38.4 & 32.30 & 0.8 & 31 & 32.5 & 34.0 & 30.9 & 32.5 & 33.69 \\
\hline Sitting knee height & 53.99 & 1.32 & 52 & 53.9 & 57.5 & 51.8 & 53.9 & 56.1 & 51.74 & 1.3 & 50 & 51.8 & 55.0 & 49.7 & 51.8 & 53.81 \\
\hline Sitting popliteal height & 44.12 & 0.93 & 43 & 44.0 & 46.5 & 42.6 & 44.0 & 45.8 & 42.63 & 0.7 & 41 & 42.5 & 44.0 & 41.1 & 42.5 & 43.82 \\
\hline Buttock popliteal height & 43.61 & 0.88 & 42 & 43.6 & 45.5 & 42.2 & 43.6 & 45.0 & 42.33 & 0.8 & 41 & 42.5 & 43.5 & 41.1 & 42.5 & 43.60 \\
\hline Weight (kg) & 56.03 & 2.70 & 53 & 55.0 & 64.0 & 51.6 & 55.0 & 60.5 & 54.27 & 2.8 & 49 & 54.4 & 60.0 & 50.0 & 54.4 & 58.52 \\
\hline
\end{tabular}

Table9: Summary of anthropometry measurement for Students aged 13-17years old $(\mathrm{n}=300)$

\begin{tabular}{|c|c|c|c|c|c|c|c|c|c|c|}
\hline Anthropometry dimensions & & $\mathrm{n}$ & Mean & SD & Min & Median & $\operatorname{Max}$ & $5 \%$-ile & $50 \%$-ile & 95\%-ile \\
\hline \multirow[t]{2}{*}{ Stature } & Boys & 150 & 158.2830 & 5.34491 & 151.0 & 157.5 & 174.0 & 149.520 & 157.5 & 167.050 \\
\hline & Girls & 150 & 155.2870 & 3.17456 & 148.0 & 154.5 & 164.0 & 150.080 & 154.5 & 160.490 \\
\hline \multirow{2}{*}{ Elbow height } & Boys & 150 & 19.4867 & 0.84156 & 17.5 & 19.5 & 22.0 & 18.107 & 19.5 & 20.867 \\
\hline & Girls & 150 & 19.4300 & 0.65317 & 18.0 & 19.5 & 22.3 & 18.359 & 19.5 & 20.501 \\
\hline \multirow[t]{2}{*}{ Sitting shoulder height } & Boys & 150 & 50.8847 & 2.98804 & 46.9 & 50.8 & 58.0 & 45.984 & 50.8 & 55.785 \\
\hline & Girls & 150 & 49.4580 & 1.51390 & 46.9 & 49.0 & 53.0 & 46.975 & 49.0 & 51.941 \\
\hline \multirow[t]{2}{*}{ Upper arm length } & Boys & 150 & 31.3980 & 3.48556 & 25.7 & 31.3 & 40.2 & 25.682 & 31.3 & 37.114 \\
\hline & Girls & 150 & 30.0280 & 1.73820 & 26.0 & 29.7 & 34.0 & 27.177 & 29.7 & 32.879 \\
\hline \multirow[t]{2}{*}{ Sitting knee height } & Boys & 150 & 53.9867 & 1.31751 & 51.8 & 53.9 & 57.5 & 61.826 & 53.9 & 56.147 \\
\hline & Girls & 150 & 51.7400 & 1.25952 & 49.8 & 51.5 & 55.0 & 49.674 & 518.0 & 53.806 \\
\hline \multirow[t]{2}{*}{ Sitting popliteal height } & Boys & 150 & 43.7933 & 0.81688 & 42.5 & 43.9 & 45.5 & 42.454 & 43.9 & 45.133 \\
\hline & Girls & 150 & 42.6300 & 0.72671 & 41.0 & 42.5 & 44.0 & 41.438 & 42.5 & 43.822 \\
\hline \multirow[t]{2}{*}{ Buttock -popliteal height } & Boys & 150 & 43.6067 & 0.87899 & 42.0 & 43.6 & 45.5 & 42.165 & 43.6 & 45.048 \\
\hline & Girls & 150 & 42.3300 & 0.77423 & 41.0 & 42.5 & 43.5 & 41.060 & 42.5 & 43.600 \\
\hline \multirow{2}{*}{ Weight (kg) } & Boys & 150 & 56.0300 & 2.70101 & 52.8 & 55.0 & 64.0 & 51.600 & 55.0 & 60.460 \\
\hline & Girls & 150 & 54.2700 & 2.59000 & 49.0 & 54.4 & 60.0 & 50.022 & 54.4 & 58.518 \\
\hline
\end{tabular}

Level of mismatch between student body dimensions and chair and desk dimensions: Figure 26 shows the number of students who fits the chair for all age groups. For aged 13 almost all students were found to be using chairs that are too deep and too high for them. For aged 14 again almost all found the chair to be too high and too deep with only $26 \%$ shows a fit in seat depth. For aged 15 only $6 \%$ manage to fit both the height and depth while for the rest its either a combination of too high and too deep or only too high. For aged $16,41 \%$ are able to fit the depth and height. The rest mostly found they are able to fit the depth but not the height and only $10 \%$ found they could not fit both the height and depth. For aged 17, 43\% manage to fit both the height and depth. The rest still found the chair too high.

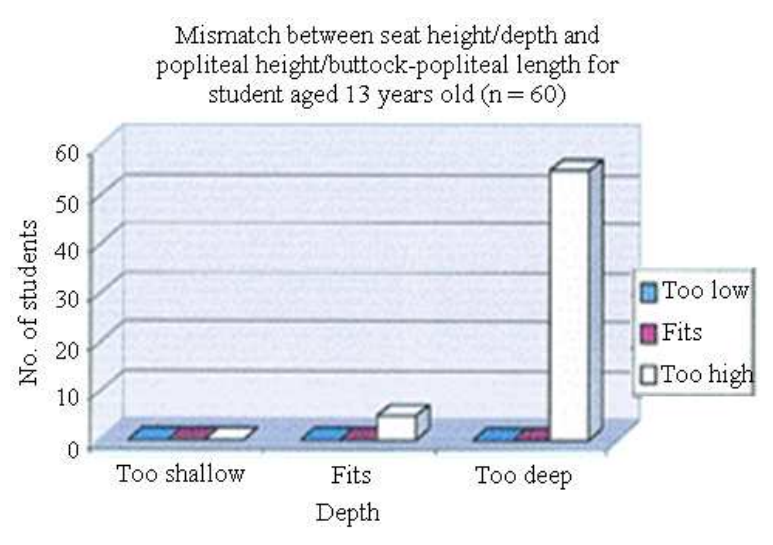

Fig. 2: Percentage of students who fit the chair aged 13 years old 


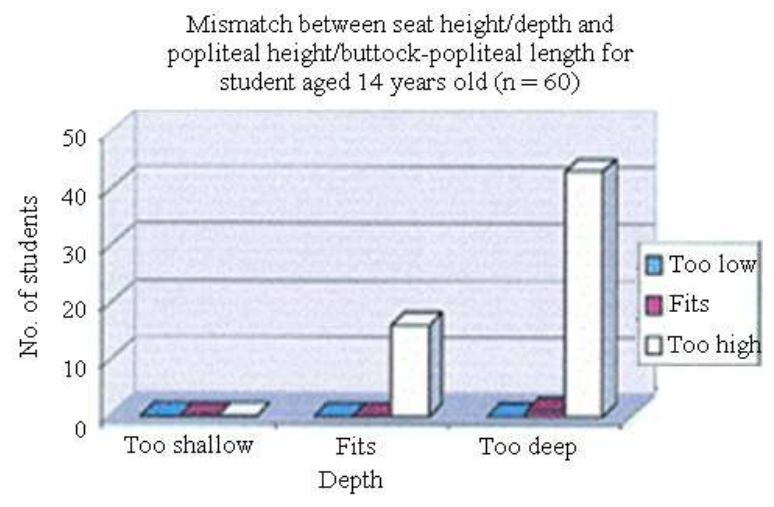

Fig. 3: Percentage of students who fit the chair aged 14 years old

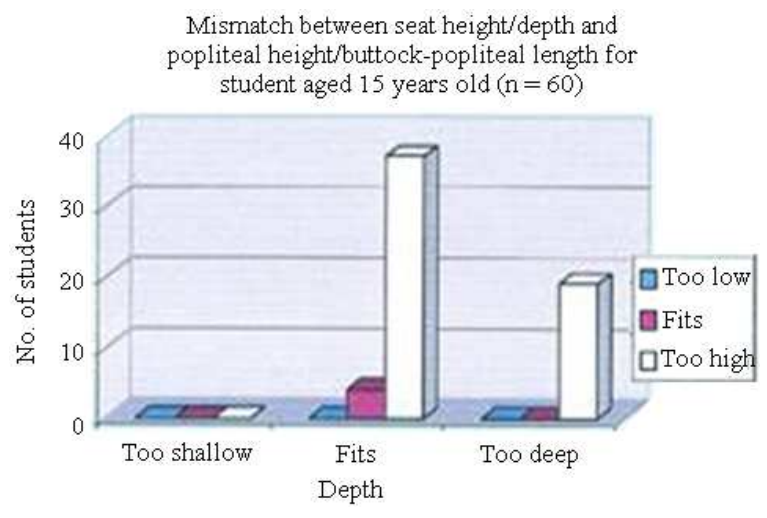

Fig. 4: Percentage of students who fit the chair aged 15 years old

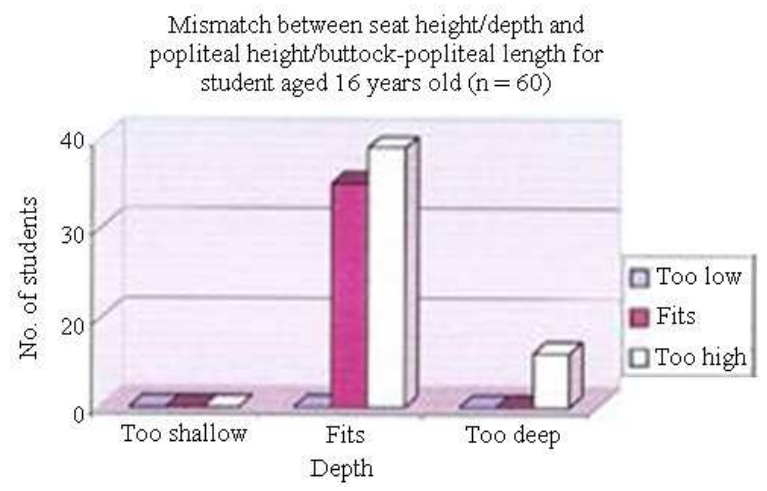

Fig. 5: Percentage of students who fit the chair aged 16 years old

The study also found that in all age groups the students have a functional elbow height of more than 8 $\mathrm{cm}$ from the acceptable functional elbow height.

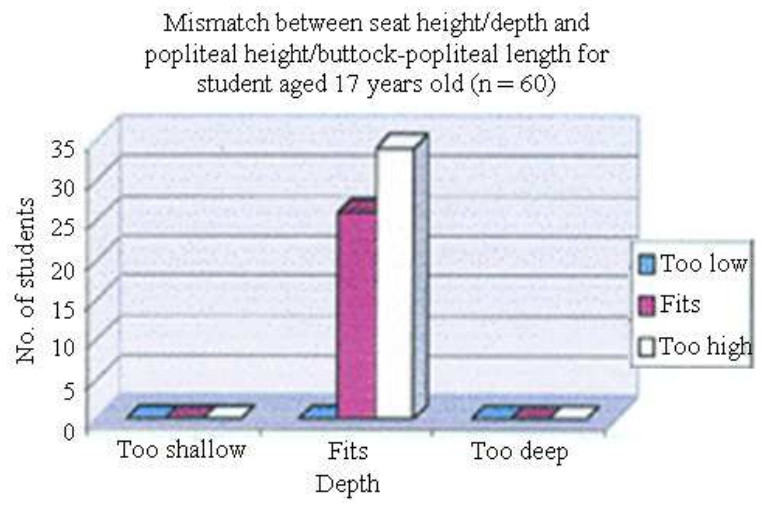

Fig. 6: Percentage of students who fit the chair aged 17 years old

\section{DISCUSSION}

The objective of this study was to examine possible mismatches between Malaysian secondary student body dimensions and the classroom furniture. It was found that for all age group there were mismatches between student body dimensions and furniture dimensions. Based on the results it is obvious that a one-size-fit all design was implemented for the chair and desk. This indicates a lack of thorough design studies of school furniture for Malaysian students. The variability of student dimension has not been taken into consideration in the design of the chair and desk for both this school. The surge of growth among 13-17 age groups causes the variability of student dimension to be widened. Although the classroom furniture were provided by the government which is assumed to be designed to fit student body dimension this study found that the design of chairs and desk may not have been done through proper ergonomics considerations which cause these mismatches to arise. While this study is only a pilot study, the finding could be an indicator of similar problem in other schools through out the country. Since the chairs and desks are supplied by the government suppliers it could have profound effect towards the well being of the current and future school children. As the OSHA act ruling is indicative of governments concerns of health and safety in the workplace including schools measures must be taken to avoid schools being noncompliance of the act. It is suggested that further studies covering other parts of the countries would be needed in order to better understand the extent of the mismatches among Malaysian student population. It is also recommended that further research on Malaysian children furniture design to be conducted so as to provide better furniture in Malaysian schools. As 
furniture and body dimension mismatches could potentially cause musculoskeletal problems, investigations of back problems among students would be necessary in order to investigate whether the above finding have taken effected Malaysian students.

\section{CONCLUSION}

The findings of this pilot study shows that further detail investigation is required. The finding could be just the tip of the iceberg where more information needs to be gathered to cater the variations of student population across age gender and location throughout Malaysia. Several issues that would be of concern are listed below for further investigation and research:

- The standard dimensions of school furniture may not be suited for Malaysian primary school children which suggest a need for children anthropometric database of Malaysian population for the purpose of design

- The design of classroom furniture involves a multidimensional problem whereby further studies are required in order to understand the key elements and its effect

- The variability of sizes requires new school furniture designs that could accommodate this variability across age and gender

- The effect of mismatches between school furniture and body dimensions have yet to be touched in Malaysian school children which suggest a study on its impact so that proper governmental regulation can be setup

Efforts are currently been made to conduct studies on the above issues which would help ensure the future work force of Malaysia are not affected by MSD which could hamper the nation building process.

\section{REFERENCES}

Chaffin, D.B. and G. Anderson, 1991. Occupational Biomechanics. The University of Michigan, ISBN: 0471601349, pp: 518.

Evans, O., B. Collins and A. Stewart, 1992. Is school furniture responsible for student seating discomfort? Proceedings of the 28th Annual Conference of the Ergonomics Society of Australia, Melbourne. http://www.pofactor.com/healthact1994.html

Lane, K.E. and M.D. Richardson, 1993. Human factors engineering and school furniture: A circular odyssey. Educ. Facility Planner J., 31: 22-23.

Malaysian Occupational Safety and Health Act, 1994. Laws pertaining to slips and falls accident. Malaysia.

Olsen, T.L., R.L. Anderson, S.R. Dearwater, A.M. Kriska and J.A. Cauley et al., 1992. The epidemiology of low back pain in an adolescent population. Am. J. Public Health, 82: 606-608. http://www.ajph.org/cgi/content/abstract/82/4/606

Parcells, C., M. Stommel and R.P. Hubbard, 1999. Mismatch of classroom furniture and student and body dimensions: Empirical findings and health implications. J. Adolesc. Health, 24: 265-273. PMID: 10227346 